\title{
Psychiatric presentation of a secondary high-grade glioma in a teenager with high-risk pre-B-cell acute lymphoid leukaemia in remission
}

\author{
Scott Sun 다, ${ }^{1}$ Denise Malicki, ${ }^{2}$ Michael Levy, ${ }^{3}$ John Ross Crawford ${ }^{4}$
}

${ }^{1}$ Department of Neurosciences, University of California San Diego, San Diego, California, USA

2Pathology, Rady Children's Hospital University of California San Diego, San Diego,

California, USA

${ }^{3}$ Neurosurgery, University of California San Diego, San Diego, California, USA

${ }^{4}$ Neurosciences and Pediatrics, University of California San Diego, La Jolla, California, USA

\section{Correspondence to} Dr John Ross Crawford; jrcrawford@ucsd.edu

Accepted 26 August 2021

Check for updates

(c) BMJ Publishing Group Limited 2021. No commercial re-use. See rights and permissions. Published by BMJ.

To cite: Sun S, Malicki D, Levy M, et al. BMJ Case Rep 2021;14:e246249. doi:10.1136/bcr-2021246249

\section{DESCRIPTION}

A 16-year-old female adolescent with a history of high-risk pre-B acute lymphoblastic leukaemia in remission after 2 years following chemotherapy and whole brain irradiation was seen for a follow-up oncological visit, where she was found to have suicidal indications. The patient's mother had died 6 months previously due to pancreatic cancer. Following evaluation in the emergency room demonstrating absence of any focal neurological sign, she was transferred to an inpatient psychiatric facility. Five days following admission, she was sent to the emergency room for evaluation of altered mental status, atypical episodes of enuresis and headaches. Neurological exam revealed a depressed affect without neurological deficits. Head CT demonstrated a large, right frontal tumour with mass effect and significant obstructive hydrocephalus (figure 1A). MRI identified a large solid and cystic mass located within the right frontal and temporal lobes with reduced diffusivity and heterogeneous enhancement (figure $1 \mathrm{~B}, \mathrm{C}$ ). The neuroradiographical differential diagnosis included high-grade glioma, anaplastic ependymoma or supratentorial embryonal tumour. History of radiation was most suggestive of a secondary malignancy. The patient underwent neurosurgical resection where histopathology revealed a hypercellular glial tumour with atypical nuclei, prominent mitoses and necrosis consistent with a diagnosis of high-grade glioma (figure 2). Next-generation sequencing on the tumour revealed a mutation in TP53 (Y126C) and variants of unknown significance in nine genes (ALK, ATRX, BRIP1, CIC, EP300, RB1, IRS2, PTCH1 and RANBP2). Germline testing revealed the same TP53 mutation. The patient received photon radiotherapy with concomitant temozolomide; unfortunately, she died 6 months after diagnosis from progressive disease.

Primary childhood brain tumours may uncommonly present with psychiatric symptoms such as psychosis, anxiety and changes in mood as opposed to more classical presenting features of headache and vomiting. ${ }^{1}$ Depression may be a rare psychiatric presenting symptom of high-grade glioma, with some cases presenting with normal neurological examination. ${ }^{2}$ The incidence of secondary malignancies presenting with primary psychiatric features is less understood. The overall cumulative incidence of brain tumours in children treated for childhood acute lymphoblastic leukaemia is under $2 \%$ based on a study population of 1612 consecutive patients

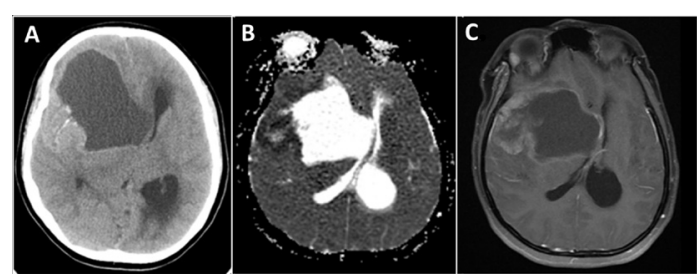

Figure 1 Neuroimaging features of secondary highgrade glioma. (A) Head CT demonstrated a large, right frontal tumour with mass effect and significant obstructive hydrocephalus. MRI identified a large solid and cystic mass located within the right frontal and temporal lobes with reduced diffusivity (B) and heterogeneous enhancement (C).

treated at St. Jude Children's Research Hospital. ${ }^{3}$ Only 10 of 1612 patients had developed highgrade glioma at a median latency of 9.1 years. ${ }^{3}$ Risk factors for secondary brain cancers include history of radiation therapy and germline mutations, both of which were present in our patient. ${ }^{3-5}$ Familial TP53 mutation, Li-Fraumeni syndrome, is a cancer predisposition condition which has been implicated in childhood acute lymphoblastic leukaemia with a risk of up to $50 \%$ within 49 years after first diagnosis of secondary malignancy. ${ }^{46}$

Our case highlights a primary psychiatric presentation of a secondary malignancy, even in the absence of any focal neurological signs. The absence of any neurological focal signs, given the size and neuroimaging characteristics, was unexpected. It is

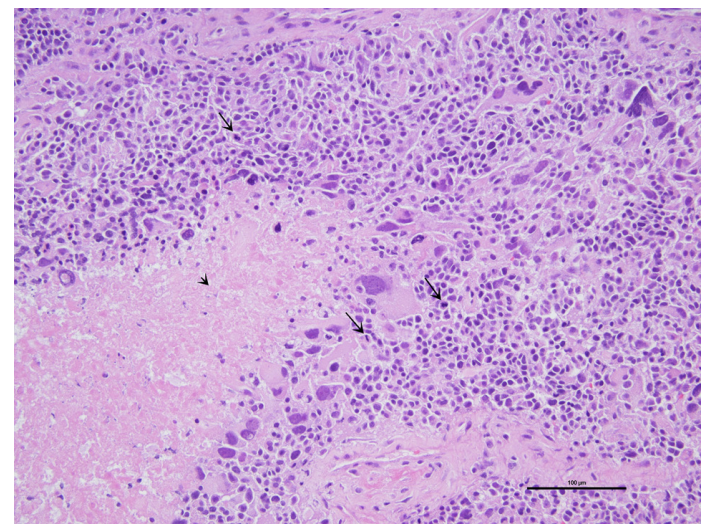

Figure 2 Neuropathology of secondary high-grade glioma. H\&E-stained section reveals a malignant glial tumour with atypical nuclei, abundant mitoses (long arrows) and necrosis (arrowhead) consistent with a diagnosis of high-grade glioma. 
possible that rapid tumour growth and the anatomical location may have been contributing factors to explain the incongruence. The unique clinical presentation, together with the novel molecular features, adds to the diversity of secondary high-grade glioma of childhood.

\section{Learning points}

- Psychiatric symptoms may be presenting features of childhood brain tumours, even in the setting of a normal neurological examination.

- Patients with TP53 germline mutations (Li-Fraumeni syndrome (LFS)) are at higher risk of secondary malignancy following radiation therapy, with high consideration for secondary high-grade glioma.

- Patients with LFS carry a high lifetime risk of cancer, nonspecific to primary or secondary malignancies, and early germline testing in at-risk patients is suggested.

Contributors All authors were responsible for the design and writing of the manuscript.

Funding The authors have not declared a specific grant for this research from any funding agency in the public, commercial or not-for-profit sectors.
Competing interests None declared.

Patient consent for publication Parent/guardian consent obtained.

Provenance and peer review Not commissioned; externally peer reviewed.

\section{ORCID iD}

Scott Sun http://orcid.org/0000-0003-0787-2533

\section{REFERENCES}

1 Zyrianova Y, Alexander L, Faruqui R. Neuropsychiatric presentations and outcomes in children and adolescents with primary brain tumours: systematic review. Brain Inj 2016:30:1-9.

2 Leo RJ, Frodey JN, Ruggieri ML. Subtle neuropsychiatric symptoms of glioblastoma multiforme misdiagnosed as depression. BMJ Case Rep 2020;13:e233208.

3 Walter AW, Hancock ML, Pui CH, et al. Secondary brain tumors in children treated for acute lymphoblastic leukemia at St Jude children's research Hospital. J Clin Oncol 1998;16:3761-7.

4 Mai PL, Best AF, Peters JA, et al. Risks of first and subsequent cancers among TP53 mutation carriers in the National cancer Institute li-fraumeni syndrome cohort. Cancer 2016;122:3673-81

5 Qian M, Cao X, Devidas M, et al. Tp53 germline variations influence the predisposition and prognosis of B-cell acute lymphoblastic leukemia in children. J Clin Oncol 2018:36:591-9.

6 Al-Husseini MJ, Saad AM, El-Shewy KM, et al. Prior malignancy impact on survival outcomes of glioblastoma multiforme; population-based study. Int J Neurosci 2019;129:447-54

Copyright 2021 BMJ Publishing Group. All rights reserved. For permission to reuse any of this content visit

https://www.bmj.com/company/products-services/rights-and-licensing/permissions/

BMJ Case Report Fellows may re-use this article for personal use and teaching without any further permission.

Become a Fellow of BMJ Case Reports today and you can:

- Submit as many cases as you like

- Enjoy fast sympathetic peer review and rapid publication of accepted articles

- Access all the published articles

- Re-use any of the published material for personal use and teaching without further permission

Customer Service

If you have any further queries about your subscription, please contact our customer services team on +44 (0) 2071111105 or via email at support@bmj.com.

Visit casereports.bmj.com for more articles like this and to become a Fellow 